\title{
Deconstructing Equivalence in the Translation of Texts from French to Indonesian
}

\author{
Sajarwa \\ Universitas Gadjah Mada \\ Email: sajarwa@ugm.ac.id
}

\begin{abstract}
Translation is a process of reproducing a source text (ST) in the equivalent target text (TT). The equivalence of translation includes the message of the text. Several factors such as writer, translator, publisher, reader, or spirit of certain era, determine the translation equivalence. In translation, equivalence is negotiated and transactioned. In consequence, it is highly likely that the current equivalence will be different in the future. Deconstruction theory claims that the relationship between a signifier and a signified is inconstant; however, it can be "deferred" to obtain a new or different relationship. As a result, a meaning may change in accordance with the will of its user. This study investigated the differences between two target texts that are the ranslations of a source text. The data were obtained from a French novel (ST) and two of its translated versions (TT1 and TT2). The result of this research indicates four differences between TT1 and TT2 translation; (1) within a period of twenty years of social and political change $(1990-2010)$, TT1 reveals regional issues, while TT2 reveals social class issues; (2) the TT2's disclosure of meaning is more direct, open, and occasionally rude than the subtle and euphemistic TT1; (3) the TT2 tends to follow ideology of foreignization by inserting foreign words or words from the source language, while the TT1 tends to follow ideology of domestication; (4) there are different viewpoints between the TT1 translator and the TT2 translator.
\end{abstract}

Keywords: translation, deconstruction, change in meaning, foreignization

\section{INTRODUCTION}

The process of transferring messages of a source language text is influenced by translator's culture, which is reflected in the way a translator comprehends, perceives, and reveals messages by the language used. The transfer of messages in translation is always marked by cultural gap of the source language and the target language. Translation is also an act of interlingual communication, whose manifestation is influenced by the culture of its language user (Hoed, 2016:19). The cultural gap will directly place a translator in a dilemmatic position (Newmark, 1998:5). On the one hand, a translator has to transfer message of the source language text into the target language accurately. On the other hand, in many cases, a translator is placed to find the equivalence which is not always appropriate in the target language (Nida and Taber, 1964: 22). The equivalence in translation is determined by several factors; writer, translator, publisher, reader, or spirit of certain age (Wills 1996: 16-28). Today, equivalence is no longer static and binary but is creative and situational (Cronin, 2003:24-25). The process of translation is no longer taking hold of equivalence principles as the main consideration. On the contrary, the process takes on interlingual and intercultural negotiation and transaction through mediation of 
a translator, as stated by Bassnet below.

"Today the movement of peoples around the
globe can be seen to mirror the very process
of translation itself, for translation is not just
the transfer of texts from one language into
another, it is now rightly seen as a process
of negotiation between texts and between
cultures, a process during which all kinds
of transactions take place mediated by the
figure of the translator." (2002: 6)

As consequences of the fact above, the symptoms of omission and betrayal occur following due to the shift of emphasis. However on the other hand, Bassnett (ibid: 1) also sees the symptom that globalization is reviving interest for search of culture of origin and identity, as well as a desire in seeking answers to the questions about identity. Therefore, translated text is a form of interpretation of an open text that corresponds with the new context. In other words, there is a deconstruction of meaning equivalence and the translation and deconstruction theory are required to explain this.

According to Derrida (1973), a relationship between the signifier (form of a sign/literary text) and the signified (meaning or content of literary text) is inconstant, and in fact, it can be "deferred" to obtain a new or different relationship. This process is known as deconstruction while the new or different relationship is known as différance. Contrary to Derrida's proposition that the signifier and the signified have a dynamic relationship, Saussure proposes that their relationship is actually static (différence). Responding Saussure's concept of différence, Derrida acknowledges that the concept is the basis for a sign's existence, which tells that meaning of a sign is simply obtained from its difference from other signs. As a further matter according to Derrida, a sign must be understood in different times and situations to make its meaning observable. Meaning of a sign is not merely observable on one occasion, but in different times and situations it can have different meanings (Hoed, 2014: 86-92). This deconstruction process, as stated by Derrida, is infinite (1973).

This study used three texts for the data. They are a French novel, Madame Bovary (source text/ ST), its Indonesian translation (target text/TT1), Nyonya Bovary by Winarsih Arifin published in 1990, and Madame Bovary (TT2), an Indonesian translation by Santi Hendrawati published in 2010 (TT2). The selection of the novel and the two translated versions as data sources of this research was based on two considerations. The first one was the reception of French people of the novel the second was the competencies of the two translators. Regarding the translators' competencies, TT1 translator (Winarsih Arifin) and TT2 translator (Santi Hendrawati) both have French-related educational degree and they lived in France for a quite long period.

Madame Bovary was written by Gustave Flaubert in 19th century, and he went to trial because of the novel. Through his novel he was accused of infringing social norms for revealing obscenity, disgrace, religion. In the novel this "infringement" is committed by the bourgeoisie (a dominating social class of capitalist regime) in particular. The life of the bourgeoisie revealed in the literary work gashed French social norms at that time. As an example, Gustave showcases hypocritical behaviors out of a sacred marriage as the characters do not adhere to the norms in their life. Flaubert was finally exonerated as a result of his persistence in defending his argument in the court. Because of the sensational trial, the novel sold 15.000 copies in 6 months. The novel is acknowledged as a literary revolution and admired not only in France, but also in Europe, the US, Asia including Indonesia (Sastriyani, 2011: 2216-233). Based on the above elaboration, the research problem of this study related to how the deconstruction of meaning equivalence of French to Indonesia translation.

\section{SOCIAL AND POLITICAL FACTORS}

This analysis of the deconstruction of meaning equivalence was done by comparing the source text (St) with Target Text 1 and Target Text 2 as shown below.

In data (1), the ST phrase la médiocrité provinciale, translated into jiwa kedaerahan yang sedang-sedang saja (mediocre spirit of regionalism) in TT1, while the TT2 translated version of the phrase is kehidupan kelas 


\begin{tabular}{|l|l|l|}
\hline 1 & ST & $\begin{array}{l}\text { Alors ils parlèrent de la médiocrité } \\
\text { provinciale, des existences qu'elle } \\
\text { étouffait, des illusions qui s'y } \\
\text { perdaient (129) }\end{array}$ \\
\hline $\mathrm{TT}_{1}$ & $\begin{array}{l}\text { Lalu mereka berbicara tentang jiwa } \\
\text { kedaerahan yang sedang-sedang } \\
\text { saja, tentang kehidupan yang tercekik } \\
\text { olehnya, tentang angan-angan yang } \\
\text { hilang di dalamnya (163) } \\
\text { [Then they talked about mediocre local } \\
\text { spirit, life suffocated by it, dreams that } \\
\text { lost in it] }\end{array}$ \\
\hline $\mathrm{TT}_{2}$ & $\begin{array}{l}\text { Lalu mereka bicara tentang } \\
\text { kehidupan kelas menengah di } \\
\text { propinsi ini, tentang kehidupan yang } \\
\text { menguasainya dan fantasi-fantasi yang } \\
\text { dihapusnya (208) } \\
\text { [Then they talked about the life of } \\
\text { middle class in this province, about } \\
\text { life that mastered it and all of the } \\
\text { fantasies erased by it] }\end{array}$ \\
\hline
\end{tabular}

menengah di provinsi ini (the life of middle class in this province). Distinction on both translations was affected by social and political change at that time. When the TT1 was first published, Indonesian political system was centralistic. The powers of government were handled directly by central the government that made local governments playing very small roles, including that spirit of provincial life was neglected. For that reason, la médiocrité provincial was translated into jiwa kedaerahan yang sedang-sedang saja. Unlike the TT2, which was published twenty years later when the social and political had changed. The change turned a centralistic government system into the de-centralistic, where there was partial shift of government system from central to local government, giving local governments a greater role. The issue of spirit of provincial/local life was no longer an intriguing issue. However, another issue emerged at the time was regarding social class, an issue which in 1990s had never come to the surface, making phrase la médiocrité provincial translated into kehidupan kelas menengah di propinsi ini in TT2.

In the era of new order, society's act and mind were shackled. People were unable to express their ideas spontaneously and sometimes they had to be euphemistic. In his article entitled Bahasa dan Pergeseran Kekuasaan, Politik Wacana di Panggung Orde Baru (Language and Power Shift, a Political Discourse on the New Order's Stage) (1996: 56-76), Hooker mentions the characteristics of political language, they are: politicization of meaning in languages expressed, causing meanings to be refined into the forms of euphemism. Euphemism used during the new order era was really a cover to the actual information about the bad existing facts or situation. Such euphemism maintained abolishment of social control effectively and also spoiled the society to become less sensitive towards development. This may cause linguistic repression to emerge. Linguistic repression is defined as suppression and restriction on people's freedom to express thoughts and feelings with language. The results are (1) the weakening of logical reasoning and sentience, (2) the weakening of language creativity, preventing language from evolving fully to the maximum level as a means to understand thoughts and feelings, (3) in turn, the impoverishment of cultures, especially in literature, and (4) number 1-3 can basically end in the death of a language (Basri, 2014:2). By contrast, the year of 2010 when TT2 was published, condition of the society had transformed into an open and outspoken society who could express directly and openly. Furthermore, this condition affected the translated text, as seen in the following data.

\begin{tabular}{|c|c|c|}
\hline 2 & $\mathrm{ST}$ & $\begin{array}{l}\text {-Attends, attends, Riboudet, } \\
\text { cria l'ecclésiastique d'une vox colère, } \\
\text { je m'en vais aller te chauffer les } \\
\text { oreilles mauvais galopin! (105) }\end{array}$ \\
\hline & $\mathrm{TT}_{1}$ & $\begin{array}{l}\text { "Awas Riboudet, tunggu saja! pedas } \\
\text { telingamu kena tanganku! teriak } \\
\text { rohaniawan itu dengan suara marah. } \\
\text { "Anak bandel! ” (134) } \\
\text { [Watch out Riboudet, just wait! I'll } \\
\text { make your ears red!" cried the priest } \\
\text { in angry voice. "You brat!'] }\end{array}$ \\
\hline & $\mathrm{TT}_{2}$ & $\begin{array}{l}\text { "Tunggu sebentar Riboudet! ” pastor } \\
\text { berteriak dengan marah. "Nanti } \\
\text { kujewer kupingmu, manusia tak } \\
\text { berguna!” (173) } \\
\text { [“Hold on Riboudet!” the pastor } \\
\text { shouted angrily."I'll tweak your ear, } \\
\text { you worthless human!] }\end{array}$ \\
\hline
\end{tabular}




\begin{tabular}{|l|l|l|}
\hline 3 & $\mathrm{ST}$ & $\begin{array}{l}\text { Après avoir laissé à la porte son } \\
\text { chapeau garni d'un crêpe, il posa sur } \\
\text { la table un carton vert (96) }\end{array}$ \\
\cline { 2 - 2 } & $\mathrm{TT}_{1}$ & $\begin{array}{l}\text { Setelah topinya yang berbahan krep } \\
\text { hitam ditinggalkannya di pintu, ia } \\
\text { meletakkan sebuah kardus hijau di atas } \\
\text { meja (124) } \\
\text { [After leaving his crape hat at the door, } \\
\text { he put down a green box on the table] }\end{array}$ \\
\hline $\mathrm{TT}_{2}$ & $\begin{array}{l}\text { Setelah memberi hormat kepada } \\
\text { keluarga yang berduka di ambang } \\
\text { pintu, ia meletakkan sebuah kotak hijau } \\
\text { di atas meja (160) } \\
\text { [After paying his respect to the } \\
\text { bereaved family at the doorway, he put } \\
\text { a green box on the table] }\end{array}$ \\
\hline
\end{tabular}

The ST phrase (2) je m'en vais aller te chauffer les oreilles is vaguely translated into pedas telingamu kena tanganku (I'll make your ears red!') in the TT1. On the other hand, the TT2 sentence nanti kujewer kupingmu (I'll tweak your ears) is clearer than the TT1. The same distinction occurs to both translations of the sentence (3) of the ST Après avoir laissé à la porte son chapeau garni d'un crêpe. In TT1 the part of the sentence becomes setelah topinya yang berbahan krep hitam ditinggalkannya di pintu (after leaving his crape hat at the door), whose meaning is implied and expressed figuratively. In the contrary, the TT2 translation version, setelah memberi hormat kepada keluarga yang berduka di ambang pintu (after paying his respect to the bereaved family on the doorway) is expressed explicitly. Moreover, in the following table, it is shown that the TT2's expression is ruder than that of TT1.

\begin{tabular}{|l|l|l|}
\hline 4 & $\mathrm{ST}$ & $\begin{array}{l}\text { "Toujours les devoirs je suisassommé } \\
\text { de ces mots-là. (135) }\end{array}$ \\
\cline { 2 - 3 } & $\mathrm{TT}_{1}$ & $\begin{array}{l}\text { «Saya sudah jera mendengar kata- } \\
\text { kata itu. (169) } \\
{[\text { I can't hear those words any more. }]}\end{array}$ \\
\cline { 2 - 3 } & $\mathrm{TT}_{2}$ & $\begin{array}{l}\text { "Saya muak mendengar kata itu! (215) } \\
{[\text { I am sick of hearing those words. }]}\end{array}$ \\
\hline
\end{tabular}

The ST sentence (4), je suis assommé de ces mots-là, is translated into TT1 Saya sudah jera mendengar kata-kata itu that is more careful than the TT2 translation, Saya muak mendengar kata itu. The word jera means unwilling (discouraged) to repeat actions, while muak (sick) has an equivalent meaning to sudah jemu, merasa jijik, and bosan (disinterested, disgusted, and bored) (KBBI, 2015). Moreover, in Table 5 the TT2 translated version of the ST Mâtin de Vinçart to Si bajingan Vinçart (That bastard, Vinçart) gives much ruder sense compared to the TT1 version $\mathbf{S i}$ Vinçart yang nakal (That naughty Vinçart).

\begin{tabular}{|l|l|l|}
\hline 5 & $\mathrm{ST}$ & Mâtin de Vinçart (266) \\
\cline { 2 - 3 } & $\mathrm{TT}_{1}$ & $\begin{array}{l}\text { Si Vinçart yang nakal (327) } \\
{[\text { That naughty Vinçart] }}\end{array}$ \\
\cline { 2 - 3 } & $\mathrm{TT}_{2}$ & $\begin{array}{l}\text { Si bajingan Vinçart (418) } \\
{[\text { That bastard, Vinçart] }}\end{array}$ \\
\hline
\end{tabular}

Language is always evolving and it is also conforming to changes in society. In the TT1 phrase ST (6) nos casquettes is translated into pet (cap), (7) nourrice is translated into inang penyusu (wet nurse), and (8) le marmot translated is to si buyung (lad). In French grammar, determiners (articles) always precede nouns; however, in Indonesian such a thing does not always occur consistently (Tobing, 2012: 222). Nowadays, words like pet, inang penyusu, and si buyung are very rarely used. Nevertheless, the TT2 contains words mostly used to this day, such as topi, $\boldsymbol{i} \boldsymbol{b} \boldsymbol{u}$ susu, and putranya (cap, wet nurse, and her son/ boy), as the translations for casquettes, nourrice, and le marmot. See Table 6, 7, and 8 below!

\begin{tabular}{|c|c|c|}
\hline \multirow[t]{3}{*}{6} & ST & Jeter nos casquettes par terre (316) \\
\hline & $\mathrm{TT}_{1}$ & $\begin{array}{l}\text { 'membanting pet ke lantai' (388) } \\
\text { [Slamming the cap on the ground] }\end{array}$ \\
\hline & $\mathrm{TT}_{2}$ & $\begin{array}{l}\text { melempar topi ke lantai' (493) } \\
\text { [Throwing the cap on the ground] }\end{array}$ \\
\hline \multirow[t]{3}{*}{7} & ST & Nourrice (162) \\
\hline & $\mathrm{TT}_{1}$ & $\begin{array}{l}\text { 'inang penyusu’ (202) } \\
\text { [wet nurse] }\end{array}$ \\
\hline & $\mathrm{TT}_{2}$ & $\begin{array}{l}\text { 'ibu susu’ (341) } \\
\text { [wet nurse] }\end{array}$ \\
\hline \multirow[t]{3}{*}{8} & ST & Rentré chez eux, le marmot (127) \\
\hline & $\mathrm{TT}_{1}$ & $\begin{array}{l}\text { 'ketika si buyung kembali pada } \\
\text { orangtuanya' (161) } \\
\text { [when the lad came home to his parents] }\end{array}$ \\
\hline & $\mathrm{TT}_{2}$ & $\begin{array}{l}\text { tiap kali putranya pulang ke rumah' } \\
\text { (205) } \\
\text { [every time her son came home] }\end{array}$ \\
\hline
\end{tabular}


One enticing effort appears in TT2 as the translator introduces words less frequently used by public like gembil (flabby) for molles in the ST as shown in data (9). On the other hand, the translator decided to use empuk (soft) on TT1, as shown in the next table. This appearance of words less frequently used in the translated texts seems to give benefit in enriching Indonesian vocabulary.

\begin{tabular}{|l|l|l|}
\hline 9 & ST & Leurs molles figures blondes (131) \\
\cline { 2 - 3 } TT1 & $\begin{array}{l}\text { Muka mereka yang empuk pirang (166) } \\
{[\text { Their fair soft faces }]}\end{array}$ \\
\cline { 2 - 3 } & TT2 & $\begin{array}{l}\text { Pipi gembil, berkulit putih, (211) } \\
{[\text { Those fair flabby cheeks }]}\end{array}$ \\
\hline
\end{tabular}

\section{LINGUISTICS FACTORS}

The difference in number 10 is that the ST Croiser les cuisses is translated into 'to cross the calves' in TT1 and 'to cross the legs' in TT2. The calves in TT1 are a part of TT2, the legs. On the other hand, the difference of $\mathrm{TT}_{1}$ and $\mathrm{TT}_{2}$ in (11) lies on a matter of superiority, ST comme un chantre de village means like a church choir singer in a village in $\mathrm{TT}_{1}$ and like a church choirmaster in a hamlet in $\mathrm{TT}_{2}$. Village is superior to hamlet.

\begin{tabular}{|l|l|l|}
\hline 10 & $\mathrm{ST}$ & Croiser les cuisses (24) \\
\cline { 2 - 3 } & $\mathrm{TT}_{1}$ & $\begin{array}{l}\text { 'menyilangkan betis' (12) } \\
\text { ['to cross the calves'] }\end{array}$ \\
\cline { 2 - 3 } & $\mathrm{TT}_{2}$ & $\begin{array}{l}\text { 'menyilangkan kaki' (10) } \\
\text { ['to cross the legs'] }\end{array}$ \\
\hline $\mathrm{TT}_{1}$ & $\begin{array}{l}\text { Il avait le cheveux coupés droit sur le } \\
\text { front, comme un chantre de village }\end{array}$ \\
$\begin{array}{l}\text { 'Renurut model penyanyi kor gereja } \\
\text { desa.' } \\
\text { ['He had his hair cut straight on the } \\
\text { forehead, like a church choir singer in } \\
\text { a village'] }\end{array}$ \\
\hline $\mathrm{TT}_{2}$ & $\begin{array}{l}\text { 'Rambutnya berponi, mirip gaya } \\
\text { rambut seorang pemimpin paduan } \\
\text { suara gereja di dusun; } \\
\text { ['He had bangs, like a church } \\
\text { choirmaster in a hamlet'] }\end{array}$ \\
\hline
\end{tabular}

Meanwhile, the difference in data (12) and (13) is synonymous. In data (12) the TT $\mathrm{T}_{1}$ of ST $\boldsymbol{D} \boldsymbol{u}$ chapeau rond is the round hat while the $\mathrm{TT}_{2}$ is the circular hat. Round is the synonym of circular. The $\mathbf{T T}_{1}$ and $\mathbf{T T}$ in data (12) are phrases, and the $\mathrm{TT}_{1}$ and $\mathrm{TT}_{2}$ in data (13) are synonymous words (i.e: his father let him run around without shoes in $\mathrm{TT}_{1}$ and his father never forbade his son to run around barefoot in $\mathrm{TT}_{2}$ ), from $\mathrm{ST}$ son père le laissait courrir sans souliers

\begin{tabular}{|c|c|c|}
\hline \multirow[t]{3}{*}{12} & ST & Du chapeau rond \\
\hline & $\mathrm{TT}_{1}$ & $\begin{array}{l}\text { 'topi bundar' } \\
\text { ['the round hat'] }\end{array}$ \\
\hline & $\mathrm{TT}_{2}$ & $\begin{array}{l}\text { 'topi bulat' } \\
\text { ['the circular hat'] }\end{array}$ \\
\hline \multirow[t]{3}{*}{13} & ST & son père le laissait courrir sans souliers \\
\hline & $\mathrm{TT}_{1}$ & $\begin{array}{l}\text { 'ayahnya membiarkannya berlarian } \\
\text { tanpa sepatu' } \\
\text { ['his father let him run without shoes'] }\end{array}$ \\
\hline & $\mathrm{TT}_{2}$ & $\begin{array}{l}\text { 'ayahnya tidak pernah melarang } \\
\text { putranya berlarian dengan kaki } \\
\text { telanjang' } \\
\text { ['his father never forbade him to run } \\
\text { around barefooted'] }\end{array}$ \\
\hline \multirow[t]{3}{*}{14} & ST & Confitures \\
\hline & $\mathrm{TT}_{1}$ & $\begin{array}{l}\text { 'manisan selai' } \\
\text { ['marmalade'] }\end{array}$ \\
\hline & $\mathrm{TT}_{2}$ & $\begin{array}{l}\text { 'selai dan manisan buah-buahan' } \\
\text { ['jam and candied fruits'] }\end{array}$ \\
\hline \multirow[t]{3}{*}{15} & ST & $\begin{array}{l}\text { Quand il entra dans les Bertaux, son } \\
\text { cheval eut peur et fit un grand écart. }\end{array}$ \\
\hline & $\mathrm{TT}_{1}$ & $\begin{array}{l}\text { Ketika ia masuk Les Bertaux, kudanya } \\
\text { kaget dan melonjak ke samping.' } \\
\text { ['When he entered Les Bertaux, the } \\
\text { horse was shocked and jumped to the } \\
\text { side.'] }\end{array}$ \\
\hline & $\mathrm{TT}_{2}$ & $\begin{array}{l}\text { 'Sewaktu melewati pintu Les Bertaux, } \\
\text { kuda yang ditunggangi Charles tiba- } \\
\text { tiba melonjak-lonjak dan mundur } \\
\text { ketakutan' } \\
\text { ['While passing through the door of } \\
\text { Les Bertaux, the horse that Charles } \\
\text { rode on suddenly bounced and, } \\
\text { frightened, retreated.'] }\end{array}$ \\
\hline
\end{tabular}

In the data (14) and (15), the TT2 give additional meanings. In data (14), TT1 translates the ST confitures into marmalade while TT2 jam and candied fruits. The additional meaning is fruits. In data (15), the ST Quand il entra dans les Bertaux, son cheval eut peur et fit un grand écart 
is translated into When he entered Les Bertaux, his horse was shocked and jumped to the side in TT1, while TT2 has it as While passing through the door of Les Bertaux, the horse that Charles rode on suddenly bounced and, frightened, retreated.

The TT1 and TT2 in the following data (16 and 17) are antonymous. The ST in data (16) Elle commençait par trois boudins circulaires is translated into 'the bottom part has three entwining threads' in TT1 and 'the top part has three entwining ribbons' in TT2. 'The top part' and 'the bottom part' are antonymous. Such is also the case with data (17) - the difference is that 'to make it fall to the floor' in TT1 is dynamic, while 'to leave it on the floor' in TT2 is static. They are the translations of ST La laisser par terre.

\begin{tabular}{|l|l|l|}
\hline 16 & $\mathrm{ST}$ & $\begin{array}{l}\text { Elle commençait par trois boudins } \\
\text { circulaires }\end{array}$ \\
\cline { 2 - 3 } & $\mathrm{TT}_{1}$ & $\begin{array}{l}\text { 'bagian bawahnya terdiri dari tiga } \\
\text { uliran yang melilit' } \\
\text { ['the bottom part has three entwining } \\
\text { threads'] }\end{array}$ \\
\cline { 2 - 3 } & $\mathrm{TT}_{2}$ & $\begin{array}{l}\text { 'bagian atasnya dililit tiga pita' } \\
\text { ['the top part has three entwining } \\
\text { ribbons'] }\end{array}$ \\
\hline \multirow{2}{*}{17} & $\mathrm{ST}^{\text {TT }}$ & $\begin{array}{l}\text { La laisser par terre } \\
\text { 'dijatuhkan ke lantai' } \\
\text { ['to drop it on the floor'] }\end{array}$ \\
\cline { 2 - 3 } & $\mathrm{TT}_{2}$ & $\begin{array}{l}\text { 'membiarkannya tergeletak di lantai' } \\
\text { ['to leave it on the floor'] }\end{array}$ \\
\hline
\end{tabular}

Take a look at the following data (18-20). TT2 tends to keep the words from ST while TT1 translates them into Indonesian.

In data (18) and (19) below, the titles Monsieur (18) and Madame (19) in ST are kept in TT2, but in TT1, they are translated into Tuan (Mr.) (18) and Widowed Lady (19). Even names of places and a play are translated in TT1, as seen in data (19) The Golden Lion Hotel (from the ST L'hôtel du Lion d'Or) and in data (20) The Parisian Kid (from the ST le Gamin de Paris). This preservation of the ST is a part of foreignization ideology. It's a translating ideology focusing on the source language (and culture), in which an "acceptable" or a "correct" translation is when we

\begin{tabular}{|c|c|c|}
\hline \multirow[t]{3}{*}{18} & $\mathrm{ST}$ & M. Lieuvain (135) \\
\hline & $\mathrm{TT}_{1}$ & $\begin{array}{l}\text { Tuan Lieuvain (170) } \\
\text { [Mister Lieuvain] }\end{array}$ \\
\hline & $\mathrm{TT}_{2}$ & Monsieur Lieuvain (216) \\
\hline \multirow[t]{3}{*}{19} & ST & $\begin{array}{l}\text { L'hôtel du Lion d'Or, tenu par Mme } \\
\text { veuve Lefrançois, sur la place d'Armes } \\
\text { (166) }\end{array}$ \\
\hline & $\mathrm{TT}_{1}$ & $\begin{array}{l}\text { Hotel Singa Emas yang dikelola oleh } \\
\text { Nyonya Janda Lefrançois di lapangan } \\
\text { umum Armes (208) } \\
\text { [The Golden Tiger Hotel run by } \\
\text { Widowed Lady Lefrançois in Armes } \\
\text { Square] }\end{array}$ \\
\hline & $\mathrm{TT}_{2}$ & $\begin{array}{l}\text { Losmen Lion d'Or yang dikelola oleh } \\
\text { Madame Lefrançois, di Place d'Armes } \\
\text { (263) } \\
\text { [Lion d'Or Inn run by Madame } \\
\text { Lefrançois in Place d'Armes] }\end{array}$ \\
\hline \multirow[t]{3}{*}{20} & ST & $\begin{array}{l}\text {-Moi, dit Binet, j'ai vu autrefois une } \\
\text { pièce intitulé 'le Gamin de Paris'. (203) }\end{array}$ \\
\hline & $\mathrm{TT}_{1}$ & $\begin{array}{l}\text { "Saya dulu pernah melihat sandiwara } \\
\text { yang berjudul 'Anak Paris'." (252) } \\
\text { [I have seen a play called 'The Parisian } \\
\text { Kid."] (252) }\end{array}$ \\
\hline & $\mathrm{TT}_{2}$ & $\begin{array}{l}\text { "Saya pernah menonton drama } \\
\text { berjudul le Gamin de Paris,', (317) } \\
\text { [I have seen a play called le Gamin de } \\
\text { Paris,,"] (317) }\end{array}$ \\
\hline
\end{tabular}

present the text as it is, with little or no change to the source text, maintaining its foreign cultural aspect (Venuti, 1995). Adopting this ideology in translating is "transference" or "decentering" (Hoed, 2006: 5) because the translation is obtained by transferring the culture of the text language to that of the source language. In this case, the translation will maintain the culture of the source text and make the cultural aspect of the source text pronounced. By maintaining the cultural aspect of the source text, the readers will feel the exoticism of the source text. The advantage of foreignization ideology is that the readers will see, know, understand, and acknowledge the culture and the language of the source text. The disadvantage is that the readers of the target text are not familiar with the language and the negative aspects of the culture in the source text can affect the readers. In data (19), the ST L'hôtel is translated into hotel 
in TT1 and inn in TT2. The words hotel and inn have similar meaning (i.e: lodgings), but a hotel has many rooms and complete facilities like a swimming pool, restaurant, gym, etc. Based on the number of rooms and the facilities, hotels are classified as one, two, three, or four-star hotels. The hotels with no such facilities are called hotel melati (budget hotel). Those types of hotel do not have star ratings. An inn is a kind of hotel melati. The difference of meaning in TT1 and TT2 also is even more pronounced in data (21) below - the ST des moyens is translated into opinion in TT1 and smart in TT2.

\begin{tabular}{|l|l|l|}
\hline 21 & ST & $\begin{array}{l}\text { - On dit pourtant qu'il a des moyens, } \\
\text { objecta l'hotesse. } \\
\text { - Des moyens ! répliqua M. Homais } \\
\text { (71) }\end{array}$ \\
\hline $\mathrm{TT}_{1}$ & $\begin{array}{l}\text { " Tapi kata orang, dia mempunyai } \\
\text { pendapat » tukas Nyonya Lefrançois. } \\
\text { «Pendapat? » tukas Tuan Homais } \\
\text { (93) } \\
\text { ["But people say he/she has an } \\
\text { opinion", Mrs. Lefrançois said. "An } \\
\text { opinion ?" Mr. Homais asked.] }\end{array}$ \\
\hline $\mathrm{TT}_{2}$ & $\begin{array}{l}\text { "Tapi mereka tetap menganggapnya } \\
\text { cerdas, " sergah induk semang. } \\
\text { "Cerdas ! » kilah Monsieur Homais } \\
\text { ('rr) } \\
\text { ['Bu they still think he/she is smart", } \\
\text { the landlady protested. 'Smart!" Mr. } \\
\text { Homais exclaimed.] }\end{array}$ \\
\hline
\end{tabular}

The word smart means 'to have a welldeveloped mind and body (to be sane and strong)', while opinion means 'thoughts, assumptions, conclusions, or a person who invents or produces something (KBBI, 2015). They have different meanings but they have a similarity, that they are both 'cognitive activities'. In data (22) ST veau à la casserole and il entre en cinquème (23) are translated into 'beef' and 'he is in the fifth grade' in TT1, but 'mutton' and 'he has to start from the eighth grade' in TT2. 'Beef' and 'mutton' give totally different meanings. Such is the case with 'he goes into the fifth grade' and 'he has to start from the eighth grade'.

In data (24) and (25), there is a difference of perspective in TT1 and TT2. The perspectives are determined by the patterns of information,

\begin{tabular}{|c|c|c|}
\hline \multirow[t]{3}{*}{22} & ST & veau à la casserole (202) \\
\hline & $\mathrm{TT}_{1}$ & $\begin{array}{l}\text { 'daging sapi' (253) } \\
\text { ['beef'] }\end{array}$ \\
\hline & $\mathrm{TT}_{2}$ & $\begin{array}{l}\text { 'daging kambing' (307) } \\
\text { ['mutton'] (307) }\end{array}$ \\
\hline \multirow[t]{3}{*}{23} & ST & $\begin{array}{l}\text { Voici un élève que je vous } \\
\text { recommande, il entre en cinquème. } \\
\text { Si son travail et sa conduite sont } \\
\text { méritoires, il passera dans les grands, } \\
\text { où l'appelle son âge. }\end{array}$ \\
\hline & $\mathrm{TT}_{1}$ & $\begin{array}{l}\text { 'Murid ini saya serahkan kepada Tuan. } \\
\text { Ia masuk kelas lima. Kalau pekerjaan } \\
\text { dan kelakuannya memuaskan, ia akan } \\
\text { dinaikkan ke kelas anak-anak yang } \\
\text { lebih dewasa yang sebenarnya lebih } \\
\text { sesuai dengan umurnya.' } \\
\text { ['I am handing this student over to } \\
\text { you, Sir. He is in the fifth grade. If his } \\
\text { works and attitude are satisfactory, he } \\
\text { will go to a class for kids who are more } \\
\text { mature, which is actually more suitable } \\
\text { for his age.] }\end{array}$ \\
\hline & $\mathrm{TT}_{2}$ & $\begin{array}{l}\text { 'Saya masukkan anak ini ke kelas } \\
\text { Anda. Ia harus mulai dari_kelas } \\
\text { delapan. Bila hasil pelajaran dan } \\
\text { perilakunya cukup baik, baru naikkan } \\
\text { dia ke kelas yang sesuai dengan } \\
\text { usianya.' } \\
\text { ['I am enrolling this kid to in your } \\
\text { class. He has to start from the eighth } \\
\text { grade. Not until his attitude and } \\
\text { studying performance are pretty good } \\
\text { will he be admitted in a class that suits } \\
\text { his age.] }\end{array}$ \\
\hline
\end{tabular}

agent, and culture. As a means of communication, language is always related to three aspects: speaker, hearer, and content. Sudaryanto stated that those three are external aspects of language because they are not the language itself. In fact, of all those three aspects, the content determines the details of language (1995: 38-41). The content (of message) is called information.

In verbal communication, the speaker presents the content or information to the hearer. The information is presented in utterances consisting of information units (Baryadi, 2002: 69). An utterance is made up of constituents. These constituents also have information, meaning that they, too, have information units. Information can be analyzed in 
two ways: 1) based on its status in the utterance, and 2) based on how important the information is. In other words, the first way is to see the status of the information and the second way is to see the urgency of the information (Baryadi, 2002: 69 and 88). The status of the information can either be old information (OI) or new information (NI), while the urgency of the information has to do with which information is important and which is less important. Halliday (1967: 212) stated that the constituent of a simple sentence that contains a more important piece of information is called theme $(\mathrm{T})$ and the less important piece of information rheme (R). He later added that theme is characterized with the constituent being at the very beginning of a simple sentence, and rheme is the rest of the sentence. Thus, every simple sentence has theme-rheme structure (T$\mathrm{R})$. Thus, the important piece of information is at the beginning of an utterance, and the rest of the sentence is less important. ST cette conjuration du monde in data (24) shows that it has an important piece of information because it is at the beginning of the sentence, while ne vous révolte pas is less important. Based on the information pattern, TT1 has the same urgency pattern with ST, that is, to state this conspiring world as an important piece of information, and does not make you want to revolt as less important. On the other hand, TT2 states the utterance you revolt as important and conspiring people less important.

\begin{tabular}{|l|l|l|}
\hline 24 & ST & $\begin{array}{l}\text {-Est-ce que cette conjuration du } \\
\text { monde ne vous révolte pas ? (137) }\end{array}$ \\
\cline { 2 - 3 } TT1 & $\begin{array}{l}\text { "Apakah dunia yang sekongkol } \\
\text { ini tidak membuat anda mau } \\
\text { memberontak?" (172) } \\
\text { [“Does this conspiring world not make } \\
\text { you want to revolt?"] }\end{array}$ \\
\cline { 2 - 2 } TT2 & $\begin{array}{l}\text { « Tidakkah Anda menentang } \\
\text { melihat sikap masyarakat yang } \\
\text { bersekongkol? (218) } \\
\text { [« Don't you revolt against the } \\
\text { conspiring people?»] }\end{array}$ \\
\hline
\end{tabular}

The difference of perspective in TT1 and TT2 in data (25) below is in the patterns of the information and the agent. The utterance in TT1 the boy came back to his parents is an important piece of information, while he is spoiled like a king's son is less important. On the other hand, TT2 shows He spoiled his son like a prince is important while his son went home less important. The boy in TT1 and he (his parent) in TT2 act as the agents.

\begin{tabular}{|l|l|l|}
\hline 25 & ST & $\begin{array}{l}\text { Rentré chez eux, le marmot fut gâté. } \\
(127)\end{array}$ \\
\cline { 2 - 3 } TT1 & $\begin{array}{l}\text { Ketika si buyung kembali ke } \\
\text { orangtuanya, ia dimanjakan bagai } \\
\text { putra raja. }(161) \\
\text { [When the boy came back to his } \\
\text { parents, he was spoiled like a king's } \\
\text { son.] }\end{array}$ \\
\hline TT2 & $\begin{array}{l}\text { Ia memanjakan putranya bak } \\
\text { pangeran, tiap kali putranya pulang ke } \\
\text { rumah. (205) } \\
\text { [He spoiled his son like a prince every } \\
\text { time his son went home.] }\end{array}$ \\
\hline
\end{tabular}

The difference of TT1 and TT2 in data (26) below lies on culture perspective. ST Charles monta, au premier, voir le malade is translated into 'Charles went to the first floor to examine the patient' in TT1, but 'Charles went to the second floor to examine his patient' in TT2. The French has the terms rez, de chaussé for the ground floor and le premier étage for the first floor, which is one floor above the ground floor. They are different in Indonesia, where the ground floor is the first floor and the floor above it is the second floor. Thus, TT1 uses French culture perspective while TT2 uses Indonesian culture perspective.

\begin{tabular}{|l|l|l|}
\hline 26 & ST & $\begin{array}{l}\text { Charles monta, au premier, voir le } \\
\text { malade }\end{array}$ \\
\cline { 2 - 3 } & TT1 & $\begin{array}{l}\text { 'Charles naik ke tingkat pertama untuk } \\
\text { memeriksa yang sakit.' } \\
\text { ['Charles went to the first floor to } \\
\text { examine the patient'] }\end{array}$ \\
\cline { 2 - 3 } TT2 & $\begin{array}{l}\text { 'Charles naik ke lantai dua untuk } \\
\text { memeriksa pasiennya.' } \\
\text { ['Charles went to the second floor to } \\
\text { examine his patient'] }\end{array}$ \\
\hline
\end{tabular}

\section{CONCLUSION}

The result of the analysis shows that there are distinctions between both TT1 and TT2. The first 
aspect relates to, fisrtly, the political and social changes within a period of twenty years from 1990 to 2010 . TT1 was influenced by regionalism issues, while the TT2 was influenced by social classes issue. Scondly, disclosures of meanings are more direct, open, and sometimes rude in TT2 than in TT2 where these are subtle and euphemistic. Thirdly, TT2 tends to follow foreignization principle by including foreign or SL words, while TT1 tends to follow domestication principles. Lastly, there seem to be different viewpoints between the two translators.

Differences present in TT1 and TT2 are the results the translators' inventive ability, creativity, intuition as well as experience and knowledge. It is believed that these are different in the two translators and they were affected by these factors when they were translating the ST. In other words, the translators performed self-reflexivity. Derrida refers to it as allegory of dissociation, a depiction of stories based on what is reflected to depict different things (Aminuddin, 2002: 190-195). The difference in the translation of the ST into TT1 and TT2 indicates a change towards the strengthening of national identity. This is shown by the disclosure of meanings that are more open and the tendency of incorporating foreign words or those belonging to the source language as a result of cross-cultural interaction.

\section{REFERENCES}

Aminuddin (2002). "Pendekatan Pasca Strukturalis: Jaques Derrida" in Analisis Wacana dari Linguistik sampai Dekonstruksi. Yogyakarta: Penerbit Kanal, pp. 155-198.

Basri, Irfani. Eufemisme dalam Jurnalistik Era Orde Baru (1966 - 1998), www.badanbahasa. kemendikbud.go.id/lamanbahasa. Accesed August 142016

Bassnett, Susan (2002). Translation Studies. Routledge, London, New York.

Cronin, Michael (2003). Translation and Globalization. Routledge, London, New York.

Derrida, Jacques (1973). Speech and Phenomena and Other Essays on Husserl's Theory of Sign. Translation from "La Voix et le Phénomène" (1967. Paris: PUF; "La Forme et le vouloirdire: Note sur la Phénomènologie du langage" in Revue internationale de philosophie, Vol.
LXXXI (1967) Paris; and "La différance" onBulletin de la Société française de la philosophie, Vo. LXII (1968). Paris: Seuil. Evanston: Northwestern University Press.

Flaubert, Gustave (1972). Madame Bovary. Paris: Gallimard. Translated Nyonya Bovary by Winarsih Arifin PT Dunia Pustaka Jaya 1990 and translated Madame Bovary by Santi Hendrawati PT Serambi Ilmu Semesta Jakarta 2010 .

Hoed, Benny H. (2006). Penerjemahan dan Kebudayaan. Jakarta: Pustaka Jaya.

(2014). Semiotika dan Dinamika Sosial Budaya. Jakarta: Komunitas Bambu.

Hooker, Virginia Matheson (1996). "Bahasa dan Pergeseran Kekuasaan, Politik Wacana di Panggung Orde Baru" in Bahasa dan Kekuasaan: Politik Wacana di Panggung Orde Baru. Editor Yudi Latif dan Idi Subandy Ibrahim. Bandung: Mizan pp. 56-76

KBBI.http://kbbi.co.id. Accessed October 32016

Newmark, Peter (1988). A Textbook of Translation. New York: Prentice Hall.

Nida, Eugene A. \& Charles R Taber (1964). The Theory and Practice of Translation. Leiden: Brill.

Sastriyani, Siti Hariti (2011). Sastra Terjemahan Prancis-Indonesia. Yogyakarta: Gadjah Mada University Press.

Tobing, Roswita Lumban (2012). Konstruksi Determinan dalam Frasa Nomina Bahasa Prancis dan Bahasa Indonesia. Jurnal Humaniora Vol. XIV No. 2, 221-230.

Venuti, L (1995). The Translator's Invisibility. A History of Translation. London, New York: Routledge.

Wills, Wolfram (1996). Übersetzungsunterricht: EineEinführun g. Günter Narr Verlag, Tübingen. 